\title{
On the /schnosoma fauna of Georgia (Coleoptera: Staphylinidae: Tachyporinae)
}

With 37 figures and 2 maps

\author{
Volker ASSING ${ }^{1}$ and Michael SCHÜLKE ${ }^{2}$
}

\author{
${ }^{1}$ Gabelsbergerstraße 2, 30163 Hannover, Germany. - vassing.hann@t-online.de \\ ${ }^{2}$ Museum für Naturkunde Berlin, Invalidenstraße 43, 10115 Berlin, Germany. - mschuelke.berlin@t-online.de \\ Published on 2017-12-08 \\ DOI: 110.21248 /contrib.entomol.67.2.195-206
}

\section{Abstract}

Three species of the Ischnosoma spelaeum group are described and illustrated, all of them most likely with very restricted distributions: Ischnosoma acutum spec. nov. (Georgia: Svaneti, Racha); I. barbigerum spec. nov. (Georgia: Svaneti); I. molle spec. nov. (Georgia: Adjara). Type material of I. major (Luze, 1901) and I. caucasicum KociAN, 1997 is revised. Additional records of previously described species of Ischnosoma STEPHENs, 1829 are reported from Georgia, partly also from other regions. Seven species of the genus have reliably been recorded from Georgia, two species of the I. pictum group and widespread, five of the I. spelaeum group and with restricted distributions. The presence of an additional species of the I. spelaeum group, I. caucasicum, requires confirmation. The distributions of the species of the I. spelaeum group are revised and mapped. Several previous literature records are zoogeographically implausible and consequently probably erroneous.

\section{Nomenclatural acts}

Ischnosoma acutum spec. nov. - urn:lsid:zoobankorg:act:62214E44-BF50-4608-95B5-BDDA2B0936FO

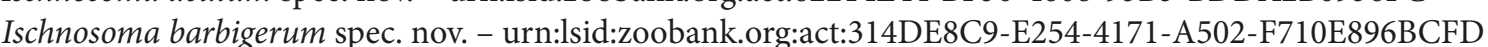

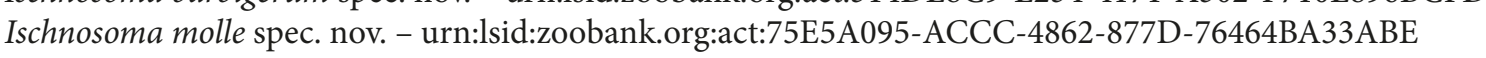

\section{Key words}

Coleoptera, Staphylinidae, Tachyporinae, Ischnosoma, Georgia, Caucasus region, West Palaearctic, taxonomy, new species, distribution maps, additional records.

\section{Zusammenfassung}

Drei sehr wahrscheinlich endemische Arten aus der Ischnosoma spelaeum-Gruppe werden beschrieben und abgebildet: Ischnosoma acutum spec. nov. (Georgien: Svaneti, Racha); I. barbigerum spec. nov. (Georgien: Svaneti); I. molle spec. nov. (Georgien: Adjara). Typenmaterial von I. major (Luze, 1901) und I. caucasicum Kocian, 1997 wird revidiert. Weitere Nachweise beschriebener Arten der Gattung Ischnosoma StePHEns, 1829 werden aus Georgien, teilweise auch aus benachbarten Regionen gemeldet. Die Gattung ist derzeit in Georgien mit insgesamt sieben sicher nachgewiesenen Arten vertreten, davon zwei weit verbreitete Arten aus der I. pictum-Gruppe und fünf endemische Arten aus der 
I. spelaeum-Gruppe. Das Vorkommen einer einer weiteren Art der I. spelaeum-Gruppe, I. caucasicum, ist zweifelhaft. Die Verbreitungsgebiete der Arten der I. spelaeum-Gruppe werden revidiert und anhand von Karten illustriert. Eine Reihe von Literaturnachweisen ist zoogeographisch nicht plausibel; offensichtlich handelt es sich um Falschmeldungen.

\section{Introduction}

According to Kocian \& SchüLke (2016), the tachyporine genus Ischnosoma STEPHENs, 1829 includes 106 described species and two subspecies distributed in all major zoogeographic regions, with the greatest diversity in the temperate zones of the Palaearctic and Nearctic regions and in the Oriental region. Kocian (2003) provided an overview of the Ischnosoma species known at that time.

The Palaearctic I. spelaeum group previously included 17 species, all of them with more or less restricted distributions. This group is of particular zoogeographic interest, as it displays a discontinuous relict distribution with two species distributed in the Chinese provinces Shaanxi and Yunnan, respectively, one species confined to North Spain, one to South Greece, and the remainder to the Caucasus region, including Turkey and the Crimean Peninsula (Kocian 1997, 2003, Kocian \& Schülke 2016, SCHÜLKe 2001, 2003, 2007). The distributions of most representatives of the I. spelaeum group are poorly known, since they have been recorded only on rare occasions. This particularly applies to species from the Caucasus region, also because a considerable proportion of the Caucasian records compiled by Kocian (1997) is based on old material without specified localities.

Remarkably, Kocian (1997) records four species of the I. spelaeum group from "Helenendorf", today Göygöl in Azerbaijan: Ischnosoma myops (EPPELSHeim, 1880), I. thoracicum (EPPELSHEIM, 1880), I. caucasicum KociAn, 1997, and I. major (Luze, 1901). These species, however, have never been reported from any other locality in Azerbaijan.

According to SchüLKe \& SMetana (2015), six species have been recorded from Georgia, the widespread and common I. splendidum (Gravenhorst, 1806) and I. longicorne (MäKLIN, 1847) of the I. pictum species group, and four species of the I. spelaeum group: I. myops, I. thoracicum, I. major, and I. campbelli Kocian, 1997. However, this list does not include I. caucasicum, whose original description is partly based on material from the Svaneti region (Kocian 1997).

The present contribution is primarily based on material recently collected in Georgia by Volker Brachat (Geretsried), Heinrich Meybohm (Großhansdorf), and Andreas Pütz (Eisenhüttenstadt). This material included not only additional records of species with poorly known distributions, but also three species new to science.

\section{Material and methods}

The material treated in this study is deposited in the following collections:
FMH Natural History Museum, Helsinki (J. Muona)

HNHM Hungarian Natural History Museum, Budapest (Gy. Makranczy)

MMB Moravske Museum, Brno (P. Baňař)

MNB Museum für Naturkunde Berlin

NHMW Naturhistorisches Museum Wien (H. Schillhammer)

NMP National Museum Prague (J. Hájek, M. Fikáček)

ZMUC Natural History Museum of Denmark, Copenhagen (A. Solodovnikov)

cAss private collection Volker Assing, Hannover

cKha private collection Eduard Khachikov (Rostov)

cKrá private collection Pavel Krásenský (Chomutov)

cPüt private collection Andreas Pütz (Eisenhüttenstadt)

cRuz private collection Jan Růžička (Prague)

cSch collection of Michael Schülke (MNB)

The morphological studies were conducted using a Stemi SV 11 microscope (Zeiss), a Discovery V12 microscope (Zeiss), and a Jenalab compound microscope (Carl Zeiss Jena). The images of the forebodies were created using a photographing device constructed by Arved Lompe (Nienburg) and CombineZ software, the remainder with a digital camera (Nikon Coolpix 995). The maps were created using MapCreator 2.0 (primap) software. Only records with specified localities are included in the maps.

Body length was measured from the anterior margin of the labrum to the apex of the abdomen, the length of the forebody from the anterior margin of the labrum to the posterior margin of the elytra, and the length of the aedeagus from the apex of the ventral process to the base of the capsule. The parameral side of the aedeagus (i.e., the side where the sperm duct enters) is referred to as the ventral, the opposite side as the dorsal aspect.

\section{Results}

\section{Ischnosoma pictum species group}

\section{Ischnosoma splendidum (GRAVENHORST, 1806)}

Material examined: Georgia: Racha: 1 \% , $4 \mathrm{~km} \mathrm{NW}$ Nikortsminda, 42²9'N, 4306'E, 1395 m, 23.V.2016, leg. Brachat \& Meybohm. Svaneti: $10^{\top}, 1$ ㅇ, MestiaUghviri Pass, $43^{\circ} 02^{\prime} \mathrm{N}, 42^{\circ} 50^{\prime} \mathrm{E}, 1900 \mathrm{~m}, 27 . V I I .2016$, leg. Meybohm; $10^{\text {* }}, 2$ ㅇ ㅇ, $4 \mathrm{~km}$ N Mazeri, $43^{\circ} 06^{\prime} \mathrm{N}$, $42^{\circ} 36^{\prime} \mathrm{E}, 1690 \mathrm{~m}, 28$. VII.2016, leg. Meybohm; 1 ㅇ, $2 \mathrm{~km}$ $\mathrm{N}$ Ipari, $43^{\circ} 01^{\prime} \mathrm{N}, 42^{\circ} 50^{\prime} \mathrm{E}, 1670 \mathrm{~m}, 29 . \mathrm{VII} .2016$, leg.

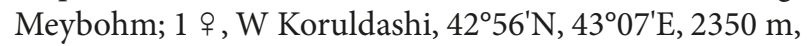
30.VII.2016, leg. Meybohm; 2 우, $7 \mathrm{~km}$ NE Ushguli, 
$42^{\circ} 57^{\prime} \mathrm{N}, 43^{\circ} 04^{\prime} \mathrm{E}, 2280 \mathrm{~m}, 31$.VII.2016, leg. Meybohm; 1 우,

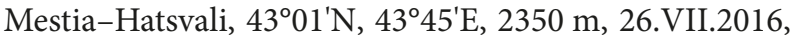
leg. Meybohm; $10^{\top}, 2$ 우 웅 Mazeri, $43^{\circ} 06^{\prime} \mathrm{N}, 42^{\circ} 36^{\prime} \mathrm{E}$, $1660 \mathrm{~m}, 26 . \mathrm{VI} .2017$, leg. Brachat \& Meybohm; 1 우, Mestia-Hatsvali, $43^{\circ} 02^{\prime} \mathrm{N}, 42^{\circ} 44^{\prime} \mathrm{E}, 1620 \mathrm{~m}, 27 . V I .2017$, leg. Brachat \& Meybohm; $20^{\top} 0^{\top}, 2$ 우 우, Ushguli, Zagaro pass, $42^{\circ} 56^{\prime} \mathrm{N}, 43^{\circ} 08^{\prime} \mathrm{E}, 2250 \mathrm{~m}, 29 . \mathrm{VI} .2017$, leg. Brachat \& Meybohm; $10^{\star}, 2$ 우 우, Ushguli, North slope, $42^{\circ} 55^{\prime} \mathrm{N}$, $43^{\circ} 01^{\prime} \mathrm{E}, 2190 \mathrm{~m}, 30 . \mathrm{VI} .2017$, leg. Brachat \& Meybohm; $10^{\top}, 4$ 우 우, Ushguli-Shkara, $42^{\circ} 56^{\prime} \mathrm{N}, 43^{\circ} 02^{\prime} \mathrm{E}, 2200 \mathrm{~m}$, 30.VI.2017, leg. Brachat \& Meybohm. Kakheti: 1 ex.,

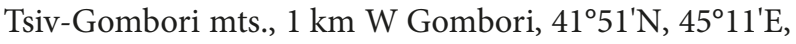
$990 \mathrm{~m}$, moist leaves near creek sifted, 9.VII.2015, leg. A. Pütz. Kvemo Kartli: $2 \sigma^{\star} o^{\star}, 1$ 오 Algeti National Park, Manglisi-Tsalka, $41^{\circ} 40^{\prime} \mathrm{N}, 44^{\circ} 18^{\prime} \mathrm{E}, 1580 \mathrm{~m}, 12 . \mathrm{VII} .2015$, leg. Brachat \& Meybohm. Mtskheta-Mtianeti: 1 우 Shatili-Mutso, $42^{\circ} 37^{\prime} \mathrm{N}, 45^{\circ} 12^{\prime} \mathrm{E}, 1510 \mathrm{~m}, 15 . \mathrm{VII} .2015$, leg. Brachat \& Meybohm; $10^{\star}$, Sno valley, $42^{\circ} 36^{\prime} \mathrm{N}, 44^{\circ} 39^{\prime} \mathrm{E}$, $1800 \mathrm{~m}, 21$. VII.2015, leg. Brachat \& Meybohm. Samtskhe-Javakheti: $10^{\prime}$, S Abastumani, $41^{\circ} 43^{\prime} \mathrm{N}, 42^{\circ} 51^{\prime} \mathrm{E}$, 1215 m, 15.V.2016, leg. Brachat \& Meybohm. Reference material deposited in cAss, cSch, and MNB.

Comment: Ischnosoma splendidum is widespread across the Palaearctic region and has been recorded also from the Nearctic and Oriental regions (SCHüLKE \& SMETANA 2015).

\section{Ischnosoma longicorne (MÄKLIN, 1847)}

Material examined: Georgia: Kvemo Kartli: $10^{\text {t }}$, Algeti National Park, W Manglisi, $41^{\circ} 42^{\prime} \mathrm{N}, 44^{\circ} 21^{\prime} \mathrm{E}$, $1120 \mathrm{~m}, 11$. VII.2015, leg. Brachat \& Meybohm; $10^{\text {* }}$, Algeti National Park, Manglisi-Tiflis, $41^{\circ} 40^{\prime} \mathrm{N}, 44^{\circ} 25^{\prime} \mathrm{E}$, 970 m, 12.VII.2015, leg. Brachat \& Meybohm. Mtskheta-Mtianeti: 1 \% , Sno valley, $42^{\circ} 35^{\prime} \mathrm{N}, 44^{\circ} 45^{\prime} \mathrm{E}, 2210 \mathrm{~m}$, 21.VII.2015, leg. Brachat \& Meybohm. SamtskheJavakheti: 1 ㅇ, $7 \mathrm{~km}$ NW Bakuriani, $41^{\circ} 47^{\prime} \mathrm{N}, 43^{\circ} 29^{\prime} \mathrm{E}$, 1454 m, 13.V.2016, leg. Brachat \& Meybohm. Reference material deposited in cAss and MNB.

Comment: This Holarctic species is common also in the Caucasus region.

\section{Ischnosoma spelaeum species group}

A compilation of all the available records with specified localities, particularly recent records, casts considerable doubt on the validity of previous records from "Helenendorf" and some other records based on old material. According to the travel report by SCHNEIDER \& LEDER (1878), the material from Helenendorf was collected in 1875 and subsequently processed and disseminated by Edmund Reitter. Based on the confirmed and more or less restricted distributions of I. myops, I. major, and particularly I. caucasicum (see Maps 1-2), Göygöl in
Azerbaijan would be far outside the respective ranges and consequently implausible. Therefore, it appears likely that the material from "Helenendorf" was either mislabelled or misidentified.

\section{Ischnosoma myops (EPPELSHEIM, 1880) \\ (Map 1)}

Material examined: Georgia: Adjara: 3 우, Skhalta valley, $41^{\circ} 34^{\prime} \mathrm{N}, 42^{\circ} 25^{\prime} \mathrm{E}, 970 \mathrm{~m}, 22 . \mathrm{VI} .2017$, leg. Brachat \& Meybohm (cAss); $10^{\star}, 7 \mathrm{~km} \mathrm{NE}$ Batumi, $41^{\circ} 39^{\prime} \mathrm{N}, 41^{\circ} 46^{\prime} \mathrm{E}$, 500-600 m, 24.VI.2017, leg. Brachat \& Meybohm (cAss). Shida Kartli: $10^{\star}, 3$ ㅇ 우 Kvishkheti, $41^{\circ} 58^{\prime} \mathrm{N}, 43^{\circ} 30^{\prime} \mathrm{E}$, $810 \mathrm{~m}, 12 . \mathrm{V} .2016$, leg. Brachat \& Meybohm (cAss); $10^{\top}$, $8 \mathrm{~km} \mathrm{SW}$ Surami, 420' $\mathrm{N}, 43^{\circ} 30^{\prime} \mathrm{E}, 960 \mathrm{~m}, 14 . \mathrm{V} .2016$, leg. Brachat \& Meybohm (cAss), 2 우 ㅇ, SE Rikoti pass, $42^{\circ} 03^{\prime} \mathrm{N}$, $43^{\circ} 30^{\prime} \mathrm{E}, 1010 \mathrm{~m}, 14 . \mathrm{V} .2016$, leg. Brachat \& Meybohm (cAss); 3 o $^{\top}$, 3 ㅇ 우, Kvishkheti, 41 ${ }^{\circ} 57^{\prime} \mathrm{N}, 43^{\circ} 29^{\prime} \mathrm{E}, 1300 \mathrm{~m}$, 24.VII.2016, leg. Meybohm (cAss). Samtskhe-Javakheti: $10^{\top}, 3$ 우 우, Timotesubani, $41^{\circ} 49^{\prime} \mathrm{N}, 43^{\circ} 31^{\prime} \mathrm{E}, 1144 \mathrm{~m}$, 13.V.2016, leg. Brachat \& Meybohm (cAss); $10^{\star}$, Bakuriani, $41^{\circ} 44^{\prime} \mathrm{N}, 43^{\circ} 43^{\prime} \mathrm{E}, 1766 \mathrm{~m}, 13 . \mathrm{V} .2016$, leg. Brachat \& Meybohm (cAss); 1 , N Abastumani, $41^{\circ} 46^{\prime} \mathrm{N}, 42^{\circ} 50^{\prime} \mathrm{E}$, 1370 m, 15.V.2016, leg. Brachat \& Meybohm (cAss). Racha: $1 \mathrm{o}^{\circ}, 4 \mathrm{~km} \mathrm{~N}$ Nakerala, $42^{\circ} 24^{\prime} \mathrm{N}, 43^{\circ} 02^{\prime} \mathrm{E}, 1150 \mathrm{~m}$, 18.V.2016, leg. Brachat \& Meybohm (cAss); $10^{\top}$, Nakerala pass, $42^{\circ} 23^{\prime} \mathrm{N}, 43^{\circ} 02^{\prime} \mathrm{E}, 1260 \mathrm{~m}, 18 . \mathrm{V} .2016$, leg. Brachat \& Meybohm (cAss); 3 o $^{\star}{ }^{\star}, 2$ 우 우, Nakerala pass, $42^{\circ} 22^{\prime} \mathrm{N}$, $43^{\circ} 02^{\prime} \mathrm{E}, 1320 \mathrm{~m}, 22 . \mathrm{V} .2016$, leg. Brachat \& Meybohm (cAss). Locality not specified: 2 exs., "Meskisches Gebirge, Leder, Reitter" (NMP, cSch).

Turkey: Rize: $120^{\star} \diamond^{\star}, 4$ 우 우, 4 exs., $32 \mathrm{~km}$ SSE Ardeşen, SE Ayder, $40^{\circ} 56^{\prime} \mathrm{N}, 41^{\circ} 09^{\prime} \mathrm{E}, 1730 \mathrm{~m}$, mixed forest (Alnus, Picea) with undergrowth (Rhododendron, Rubus), sifted, 10.VII.2008, leg. Assing \& Schülke (cAss, cSch). Artvin: 1 ex., $20 \mathrm{~km} \mathrm{~W}$ Borçka, Cankurtaran geçidi, $41^{\circ} 24^{\prime} \mathrm{N}$, $41^{\circ} 32^{\prime} \mathrm{E}-41^{\circ} 24^{\prime} \mathrm{N}, 41^{\circ} 31^{\prime} \mathrm{E}, 730-775 \mathrm{~m}$, margin of deciduous forest with dominant Fagus and Castanea, 29.-30. VI.2004, leg. Hájek \& Růžička (cRuz). Locality doubtful: 1 ơ, 1 ex., "Helenendorf” (NMP, cSch).

Comment: Ischnosoma myops is the most widespread representative of the I. spelaeum group in the Caucasus region, its confirmed range extending from Northeast Anatolia (Rize, Artvin) to central Georgia, with the easternmost record at $43^{\circ} 42^{\prime}$ eastern longitude (Map 1). The previous and above records from Göygöl ("Helenendorf") in Azerbaijan (see grey circle in Map 1) are far outside the confirmed range and consequently doubtful (see comment above). For other previous records see KociAn (1997) and SCHÜLKE $(2001,2003,2007)$. SAMIN $\&$ al. (2011a, b) reported the species from Ardabil and Fars provinces, Iran. These records, however, are far outside the confirmed distributions of I. myops and of the I. spelaeum group as a whole. There is little doubt that they are based on misidentification and most likely refer to I. splendidum or I. longicorne, if they refer to Ischnosoma at all. 
The above male from the environs of Batumi is remarkably small (body length $2.8 \mathrm{~mm}$; length of forebody $1.3 \mathrm{~mm}$ ). The male primary and secondary sexual characters, however, are identical to those of other males of I. myops examined.

\section{Ischnosoma major (LUZE, 1901) \\ (Map 2)}

Type material examined: Lectotype ${ }^{\star}$ [dissected prior to present study]: "Kaukas, Leder, Helenendorf. / major m. det. Luze / c. Eppelsh. Steind. d. / Typus / Lectotypus o Mycetoporus major Luze, des. M. Kocian 1994 / Ischnosoma major Luze [sic], M. Kocian det. 94" (NHMW). Paralectotypes 1 \%: "Kaukasus, Helenendorf. / major m. det. Luze / Typus / Paralectotypus + Mycetoporus major Luze, des. M. Kocian 1994 / Ischnosoma major Luze, M. Kocian det. 94" (NHMW); 1 \%: "Kaukasus, Helenendorf. / major m. det. Luze / ex coll. Luze / Typus Mycetoporus major Luze / Paralectotypus of Mycetopo- rus major Luze, des. M. Kocian 1994 / Ischnosoma major Luze, M. Kocian det. 94" (NHMW).

Additional material examined: Georgia: MtskhetaMtianeti: $4 \sigma^{\top} \sigma^{*}$, Stepanzminda, $42^{\circ} 40^{\prime} \mathrm{N}, 44^{\circ} 37^{\prime} \mathrm{E}$, 2120 m, 20.VII.2015, leg. Brachat \& Meybohm (cAss, cSch), $10^{\star}$, Sno valley, $42^{\circ} 35^{\prime} \mathrm{N}, 44^{\circ} 45^{\prime} \mathrm{E}, 2210 \mathrm{~m}$, 21.VII.2015, leg. Brachat \& Meybohm (cAss); $10^{*}$ [dissected prior to present study], Kazbeg, 1879, leg. Leder (NHMW).

Identification doubtful: 1 , Kvemo Kartli, Algeti National Park, W Manglisi, $41^{\circ} 42^{\prime} \mathrm{N}, 44^{\circ} 18^{\prime} \mathrm{E}, 1210 \mathrm{~m}$, 11.VII.2015, leg. Brachat \& Meybohm (cAss).

Comment: Ischnosoma major was originally described from the type locality "Helenendorf" [= Göygöl] in Azerbaijan and subsequently reported also from Teberda in the Northwest Caucasus (Kocian 1997). Schülke \& Smetana (2015), however, list this species only from Georgia.

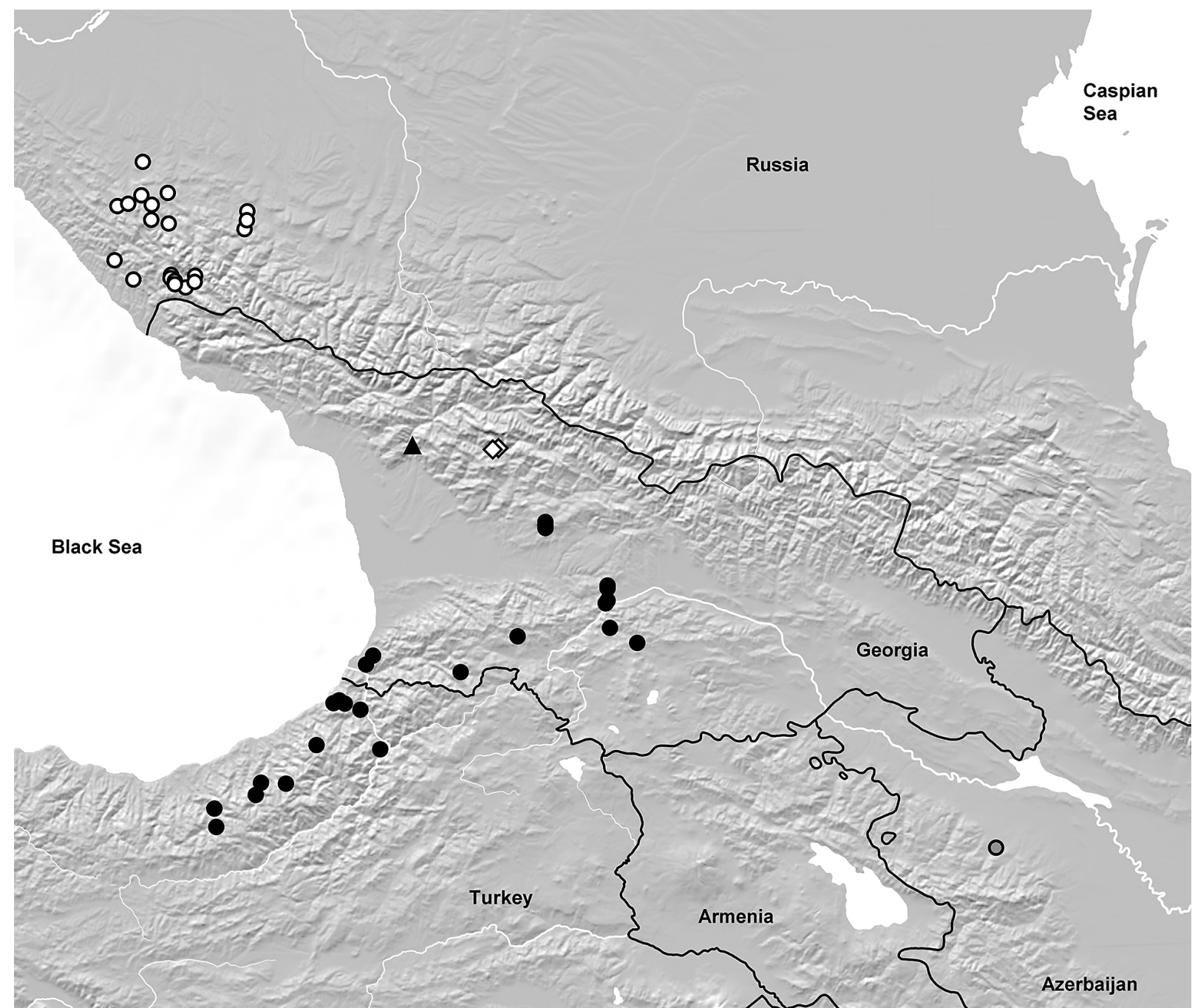

Map 1: Distributions of species of the Ischnosoma spelaeum group in the Caucasus region, based on revised and reliable records: I. caucasicum (white circles); I. barbigerum (black triangle); I. acutum (white diamonds); I. myops (black circles). Grey circle: doubtful locality "Helenendorf” (today Göygöl). 
A revision of the type material and an additional male from Kazbeg in the collections of NHMW revealed that, from what can be seen of the male sexual characters, they are conspecific with the males from Mtskheta-Mtianeti listed above. However, the revised distribution (Map 2) suggests that both the type localiy and the record from Teberda are doubtful.

\section{Ischnosoma campbelli KocIAN, 1997 (Map 2)}

Material examined: Russia: Krasnodarskiy Kray: 1 ㅇ,

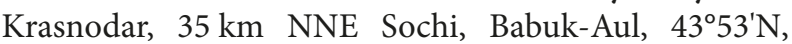
$39^{\circ} 49^{\prime} \mathrm{E}, 560 \mathrm{~m}$, Fagus orientalis and Castanea sativa forest, litter and bark sifted, 11.VII.2011, leg. Assing (cAss); $10^{7}$,

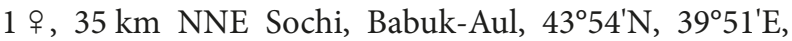
$1160 \mathrm{~m}$, beech forest with rhododendron, rhododendron litter sifted, 14.VII.2011, leg. Assing (cAss); 1 o , 1 ex., Sochi, Krasnaya Polyana, 16.V.-5.X. 1988, leg. Hippa \& Vilkamaa (FMH, cSch); 1 ex., Aibga (NMP).
Comment: The original description of I. campbelli is based on a male from a locality in Abkhazia (Kocian 1997). SCHÜLKE (2001) subsequently reported the species from two localities near Krasnaya Polyana (Russia). The currently known distribution is illustrated in Map 2.

\section{Ischnosoma caucasicum KocIAN, 1997}

(Figs 19-23, 34-35, Map 1)

Type material examined: Paratype $\sigma^{\star}$ : "Caucasus. Swanetien. Leder. Reitter. / 878, 78 / Mycetoporus spelaeus, det. J. Frivaldszky / Paratypus o Ischnosoma caucasicum, M. Kocian des. 1996" (HNHM).

Additional material examined: Russia: Krasnodarskiy Kray: $10^{\star}, 4$ km NNW Krasnaya Polyana, Atchishkho Mt., $43^{\circ} 43^{\prime} \mathrm{N}, 40^{\circ} 10^{\prime} \mathrm{E}, 1150 \mathrm{~m}$, beech forest, leaf litter sifted, 19.VII.2011, leg. Assing (cAss); 3 ㅇ ㅇ , $4 \mathrm{~km} \mathrm{NNW}$

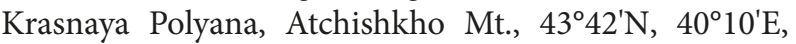
$1130 \mathrm{~m}$, beech forest with rhododendron, leaf litter sifted, 19.VII.2011, leg. Assing (cAss); 2 exs., Aibgo [Mt. Aibga]

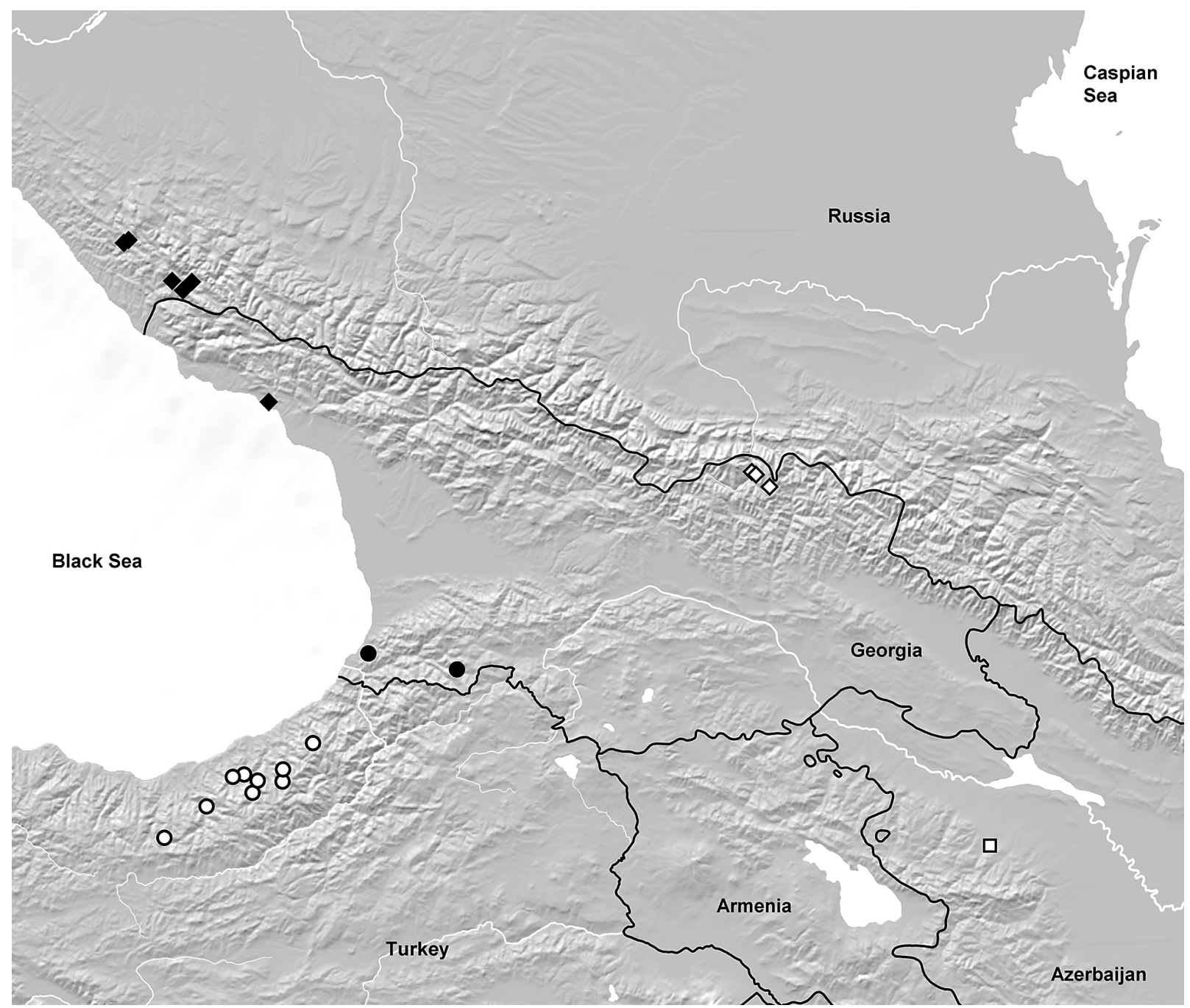

Map 2: Distributions of species of the Ischnosoma spelaeum group in the Caucasus region, based on revised and reliable records: I. campbelli (black diamonds); I. major (white diamonds); I. molle (black circles); I. solodovnikovi (white circles). White square: doubtful locality "Helenendorf" (today Göygöl). 
(NMP, cSch); 1 ㅇ, ex., Kavkazsky Nature Reserve, Azishsky pass, 14.-26.VIII.2013, leg. Chumachenko (cKha, cSch); 1 o, 2 exs., Kavkazsky Nature Reserve, Instruktorskaya Shchel gorge, 23.VIII.-11.IX.2013, leg. Chumachenko (cKha, cSch); $1 o^{\text {t }}, 1$ ex., Lagonaksky

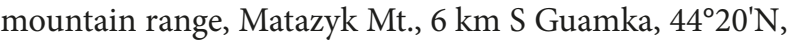
3955'E, $1000 \mathrm{~m}, 20$. V.2014, leg. Pütz (cPüt, cSch); 1 ex., Lagonaksky mountain range, Matazyk Mt., 8 km S Guamka, $44^{\circ} 09^{\prime} \mathrm{N}, 39^{\circ} 55^{\prime} \mathrm{E}, 1080 \mathrm{~m}$, sifted, 21.V.2014, leg. Pütz (cPüt); 1 ex., right bank of Malaya Laba river, Chernoechie env., $43^{\circ} 59^{\prime} \mathrm{N}, 40^{\circ} 43^{\prime} \mathrm{E}, 770 \mathrm{~m}$, sifted and pitfall traps, 21.V.2014, leg. Pütz (cPüt); 1 ex., left bank of Shedok river, Shedok env., $44^{\circ} 05^{\prime} \mathrm{N}, 40^{\circ} 44^{\prime} \mathrm{E}, 670 \mathrm{~m}$, pitfall traps and sifted, 24.V.2014, leg. Pütz (cPüt); 6 exs., right bank of Malaya Laba river, Burnaya env., $44^{\circ} 02^{\prime} \mathrm{N}, 40^{\circ} 44^{\prime} \mathrm{E}$, 740 m, 24.V.2014, leg. Pütz (cPüt, cSch); 1 o $^{*}, 3$ exs., $\mathrm{S}$ slopes of Chernogorie mountain range, Otdalyrennyi env., $44^{\circ} 05^{\prime} \mathrm{N}, 39^{\circ} 44^{\prime} \mathrm{E}, 780 \mathrm{~m}, 23 . \mathrm{V} .2014$, leg. Pütz (cPüt, cSch); 1 ㅇ, Sochi, Alek mountain range, upper course of river Khota, 750 m, VIII.2001, leg. Koval (cSch); $10^{*}, 1$ 우 1 ex., Mt. Chernogor, $20 \mathrm{~km} \mathrm{NW}$ of Mt. Fisht, $700 \mathrm{~m}$, in forest litter, 11.VI.1999, leg. A. Solodovnikov (ZMUC, cSch). Republic of Adygea: $1 \sigma^{\star}$, Belaya river env., $420 \mathrm{~m}$, 15.VII.1997, leg. Kopecký \& Švarc (cKrá). Locality not specified: 2 exs., "Circassien, Leder, Reitter" (MMB).

Comment: The original description of I. caucasicum is based on material from "Circassien" (type locality), "Helenendorf”, "Swanetien", "Caucasus", and "Krasnaja Poljana” (Kocian 1997), i.e., from the Russian part of the West Caucasus, Georgia, and Azerbaijan. Nevertheless, the species is listed in the Palaearctic Catalogue (SCHÜLKe \& SMETANa 2015) only for Russia. Subsequent records were published from several localities in Krasnodarskiy Kray and the Republic of Adygea, as well as from "Circassien" and "Caucasus" without further specification SCHÜLKE (2001, 2003).

According to the original description, there should be four paratypes of I. caucasicum from "Helenendorf" and one from "Swanetien" in the collections of the natural history museum in Budapest. These specimens were looked for by the curator in charge. There is no material from "Helenendorf" in these collections (MAKRANCZY e-mail, 29 September 2017). The sole paratype found is an undissected male from "Swanetien". An examination of this specimen revealed that it is conspecific with the recently collected material from Krasnodarskiy Kray and Adygea. Nevertheless, in view of the revised distribution of I. caucasicum, the records of two other closely related species in Svaneti, and of other evidently mislabelled, old Caucasian specimens of the I. spelaeum group, the presence of I. caucasicum in Svaneti requires confirmation. Based on recent records and on the distributions of the closely related I. acutum and I. barbigerum, the range of I. caucasicum is confined to the West Caucasus (Map 1). The record from Göygöl ("Helenendorf") in Azerbaijan (see grey circle in Map 1) is clearly based on mislabelled or misidentified material. Reliable records of I. caucasicum from Georgia are at present unknown. Its presence in West Abkhazia, however, would not seem unlikely. The male sexual characters are illustrated in Figs 19-23, 34-35.

\section{Ischnosoma thoracicum (EPPELSHEIM, 1880)}

Comment: Schülke \& SMetana (2015) list I. thoracicum only for Georgia. According to Kocian (1997), who designated a lectotype, the type locality is "Helenendorf" in Azerbaijan. Subsequent records have never been published, so that, based on currently available evidence, this species does not belong to the fauna of Georgia. However, there is a possibility that the lectotype was mislabelled (see comments in the sections on the I. spelaeum group, on I. myops, I. caucasicum, and I. major), so that the true distribution of I. thoracicum requires confirmation.

\section{Ischnosoma acutum spec. nov.

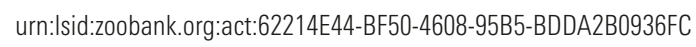 (Figs 1-10, 32, 36, Map 1)}

Type material: Holotype ơ: "N42 $488^{\prime} 21$ E42 40 '43 (25), Georgien Svaneti, Lentekhi NW 1240 m, Brachat \& Meybohm 2.7.2017 / Holotypus o Ischnosoma acutum sp. n. det. V. Assing 2017” (cAss). Paratype ㅇ: “ $42^{\circ} 47^{\prime} 53$ E42 $38^{\prime} 01$ (17), Georgia Ratscha, Lentekhi $10 \mathrm{~km} \mathrm{W,}$ 1100 m, Brachat \& Meybohm, 20.V.2016” (cAss).

Etymology: The specific epithet (Latin, adjective) alludes to the conspicuously acute apex of the ventral process of the aedeagus (ventral view).

Description: External characters (Fig. 1) as in I. caucasicum, except as follows:

body somewhat smaller: body length 3.8-4.2 mm; length of forebody $1.7 \mathrm{~mm}$; antennae somewhat shorter: length of antenna $1.3 \mathrm{~mm}$; eyes slightly smaller; elytra with sutural series composed of 5-6 coarse punctures.

$\sigma^{\star}$ : sternite VII (Figs 2-3) with an extensive cluster of dense pale short setae in postero-median portion and with nearly truncate posterior margin; sternite VIII (Figs 4-5) with strongly concave posterior margin, near this concavity with conspicuously dense, long, relatively stout setae arranged in palisade fashion, anterior to this cluster with a cluster of dense pale and short setae; aedeagus (Figs 6-10) $0.75 \mathrm{~mm}$ long, with the apex of ventral process conspicuously long and acute in ventral view and of characteristic shape in lateral view; internal structures, including apical internal structures, distinctly sclerotized; parameres with somewhat abruptly narrowed apex and each with 11-12 setae.

Comparative notes: Regarding the shapes and chaetotaxy of the male sternites VII and VIII, I. acutum is most simi- 
lar to I. caucasicum and I. campbelli. Aside from its smaller size, somewhat shorter antennae, and the much longer and more acute apex of the ventral process of the aedeagus, the new species is distinguished from them as follows:

from I. caucasicum by the extensive cluster of dense fine setae on the male sternite VII (I. caucasicum: with a small postero-median cluster of few stout setae), the shape and chaetotaxy of the male sternite VIII (I. caucasicum: posterior margin less strongly concave, posterior portion with a more extensive cluster of transversely trapezoid shape with denser, more regular, and less stout setae not arranged in palisades, anterior to this cluster with a more extensive cluster of denser and longer pale setae), and by a longer aedeagus with internal structures of different shapes;

from I. campbelli by less distinct microsculpture on the pronotum, fewer punctures along the elytral suture, less dense and slightly coarser punctation of the abdomen, the presence of a cluster of dense setae in the postero-median portion of the male sternite VII (absent in I. campbelli), the shape and chaetotaxy of the male sternite VIII (I. campbelli: posterior margin more strongly concave, posterior cluster of modified setae arranged in less dense palisades and narrower, median cluster of dense pale setae more extensive), and a more slender aedeagus with internal structures of different shapes.

For illustrations of I. caucasicum and I. campbelli see Figs 19-23 and Kocian (1997).

Distribution and natural history: The specimens were collected in two close localites near Lentekhi, on either of the border between Svaneti and Racha regions, Georgia (Map 1). They were sifted from leaf litter in a mixed deciduous forest (type locality; Fig. 36) and on a north slope with hazelnut and beech at altitudes of 1240 and 1100 m, respectively (Меувонм pers. comm.).

\section{Ischnosoma barbigerum spec. nov.

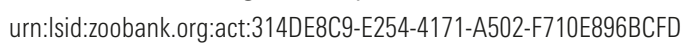 (Figs 11-18, 37, Map 1)}

Type material: Holotype $0^{*}$ : “N42 $49^{\prime} 02$ E42 $01^{\circ} 52$ (10), Georgien Svaneti, Jvari ca. $20 \mathrm{~km} \mathrm{~N} 600 \mathrm{~m}$, Brachat \& Meybohm 25.6.2017 / Holotypus o Ischnosoma barbigerum sp. n. det. V. Assing 2017” (cAss).

Etymology: The specific epithet (Latin, adjective: bearded) alludes to the characteristic clusters of dense setae on the male sternite VIII.

Description: Body length $4.3 \mathrm{~mm}$; length of forebody $2.0 \mathrm{~mm}$; length of antenna $1.3 \mathrm{~mm}$. Elytra with sutural series composed of 5-7 moderately coarse punctures. Based on external characters (Fig. 11) indistinguishable from the geographically close I. acutum.

$\sigma^{\star}$ : sternite VII (Figs 12,33) with an extensive cluster of dense pale short setae in postero-median portion and near posterior margin with modified short and stout setae; sternite VIII (Figs 13-14) with moderately concave posterior margin, in postero-median portion with a transverse cluster of very dense long setae not arranged in palisades, anterior to this cluster with dense shorter and paler setae; aedeagus (Figs 15-18) $0.7 \mathrm{~mm}$ long, apex of ventral process subapically abruptly narrowed in ventral view and very acute in lateral view; basal internal structures distinctly, apical internal structures weakly sclerotized; parameres regularly tapering apicad and with 10-11 setae each.

Comparative notes: Ischnosoma barbigerum is readily distinguished from the externally similar I. acutum, the only other representative of the I. spelaeum group recorded from Svaneti, by the shape and chaetotaxy of the male sternite VIII and by the completely different shape of the apex of the ventral process of the aedeagus. It differs from I. caucasicum, which it most resembles in the chaetotaxy of the male sternite VIII, by slightly smaller body size, smaller eyes, shorter antennae, a male sternite VII with an extensive postero-median cluster of dense short setae, a male sternite VIII with a narrower posterior cluster of shorter and less dense setae and with less stout long black setae on either side of the posterior median setae, and by a more slender aedeagus with a less broad ventral process (ventral view), with a much more slender and acute apex of the ventral process (lateral view), and with internal structures of different shapes. For illustrations of I. caucasicum see Figs 19-23.

Distribution and natural history: The type locality is situated to the north of Jvari, Svaneti region, Georgia (Map 1). The holotype was sifted from leaf litter near a stream in a mixed deciduous forest (Fig. 37) at an altitude of $600 \mathrm{~m}$ (Меувонм pers. comm.).

\section{Ischnosoma molle spec. nov.

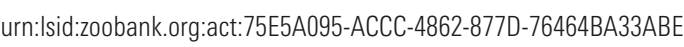 (Figs 24-32, Map 2)}

Type material: Holotype ơ: “N41³9'12 E41²45'36 (9), Georgien Adjara, Batumi 7 km NE 500-600 m, Brachat \& Meybohm 24.6.2017 / Holotypus ơ Ischnosoma molle sp. n. det. V. Assing 2017” (cAss). Paratypes: $10^{\star}, 1 \%$ : same data as holotype (cAss, cSch); 1 \%: "N4134'23 E42 $25^{\prime} 06$ (6), Georgien Adjara, Skhalta - Tal 970 m, Brachat \& Meybohm 22.6.2017” (cAss).

Etymology: The specific epithet (Latin, adjective: soft) alludes to the weakly sclerotized aedeagus, including its internal structures.

Description: Body length 4.7-6.1 mm; length of forebody 2.1-2.5 mm; length of antenna $1.5-1.7 \mathrm{~mm}$. Based on external characters (Fig. 24) indistinguishable from I. solodovnikovi SснüLKe, 2001 (Northeast Anatolia: Trabzon, Rize).

$\sigma^{*}$ : sternite VII (Figs 25-26) with an oblong and extensive cluster of dense pale short setae in postero-median 
portion, near middle of posterior margin with modified short and stout setae; sternite VIII (Figs 17-28) with broadly and deeply concave posterior margin, in posteromedian portion with cluster of dense and moderately long setae; aedeagus (Figs 29-32) $0.75 \mathrm{~mm}$ long, apex of ventral process subapically abruptly narrowed and apically acute in ventral view; internal structures weakly sclerotized; parameres regularly tapering apicad and with approximately 13 setae each.

Comparative notes: Based on the highly similar external and male sexual characters (including the shape of the apex of the ventral process of the aedeagus), I. molle is undoubtedly most closely allied to I. solodovnikovi, from which it differs only by a denser postero-median cluster of setae on the male sternite VIII, a less oblong male sternite VIII with a more broadly and more deeply concave posterior margin and with a more defined cluster of denser and longer setae, and an aedeagus with a more acute apex of the ventral process (ventral view) and with less distinctly sclerotized internal structures of different shapes.

Distribution and natural history: This species is currently known from two localities in the southwestern Caucasus Minor, Adjara region, Southwest Georgia (Map 2). Its known distribution is separated from the allopatric range of I. solodovnikovi by two major river valleys.

The specimens were collected by sifting leaf litter in a mixed deciduous forest with walnut, chestnut, beech, laurel, and rhododendron (type locality) and in a mixed deciduous forest with beech and rhododendron at altitudes between approximately 550 and 970 m (Меувонм pers. comm.).

\section{Ischnosoma solodovnikovi ScHÜLKE, 2001 (Map 2)}

Material examined: Turkey: Rize: $3 \sigma^{\top} o^{*}, 32 \mathrm{~km}$ SSE Ardeşen, SE Ayder, 40 $56^{\prime} \mathrm{N}, 41^{\circ} 09^{\prime} \mathrm{E}, 1730 \mathrm{~m}$, mixed forest (Alnus, Picea) with undergrowth (Rhododendron, Rubus), sifted, 10.VII.2008, leg. Assing \& Schülke (cAss, $\mathrm{cSch}$ ); 2 우 우, $25 \mathrm{~km} \mathrm{~S}$ Pazar, $40^{\circ} 58^{\prime} \mathrm{N}, 40^{\circ} 52^{\prime} \mathrm{E}, 670 \mathrm{~m}$, moist mixed forest (Picea, Castanea, Rhododendron), litter sifted, 11.VII.2008, leg. Assing \& Schülke (cAss, cSch).

Comment: The known distribution of I. solodovnikovi (Map 2) is confined to Trabzon and Rize provinces, Turkey (SchüLKe 2001, 2007; material examined). The species has never been reported from Georgia, but is included here to illustrate its distribution in relation to that of its hypothesized closest relative, I. molle.

\section{Acknowledgements}

We are indebted to Volker Brachat (Geretsried) and Heinrich Meybohm for the generous gift of Staphylinidae from Georgia. Heinrich Meybohm provided the habitat photos. Harald Schillhammer (NHMW) and György Makranczy (HNHM) communicated information on type material in their respective collections and instantaneously responded to last-minute loan requests.

\section{References}

Kocian, M. 1997: A revision of Western Palearctic species of the genus Ischnosoma STEPHENs (Coleoptera, Staphylinidae: Tachyporinae). - Acta Universitatis Carolinae Biologica 40(1996): 241-299.

Kocian, M. 2003: Monograph of the world species of the genus Ischnosoma (Coleoptera: Staphylinidae). - Acta Universitatis Carolinae Biologica 47: 3-153.

Kocian, M. \& Schülke, M. 2016: New species and records of Ischnosoma Stephens (Coleoptera, Staphylinidae, Tachyporinae) from China. _- Zootaxa 4105(3): 201-242. - htttp://www.mapress.com/j/zt/article/view/1 Zootaxa.4105.3.1/0 [accessed $20 \overline{1} 7 / \overline{1} 1 / 0 \overline{0}]$.

SAMIN, N.; ZHOU, H.-Z.; SAKenin, H.; Imani, S. \& RAstegar, J. 2011a: A contribution to the knowledge of tachyporine group of rove beetles (Coleoptera: Staphylinoidea: Staphylinidae) from Iran. - Linzer Biologische Beiträge 43(2): 1579-1586. _ - 'http:// www.zobodat.at/pdf/LBB_0043_2_1579-1586.pdf [accessed $2017 / 1 \overline{1} / 07]$.

Samin, N.; Zhou, H.-Z.; Imani, S. \& Rastegar, J. 2011b: A contribution to the knowledge of Iranian Staphylinidae (Coleoptera: Staphylinoidea). - Archives of Biological _. Sciences 63(4): 1235-1243. - DOI: $10.2298 / \mathrm{ABS} 1104235 \mathrm{~S}$

SCHNEIDER, Ö. \& LEDER, H. 1878: Beiträge zur Kenntniss der kaukasischen Käferfauna. - Verhandlungen des Naturforschenden Vereins in Brünn 16(1877): 3-258 +4 plates.

SchÜlKe, M. 2001: Eine neue Art und neue Funde von Arten der Gattung Ischnosoma STEPhens, 1829 (Insecta: Coleoptera: Staphylinidae: Tachyporinae). - Reichenbachia, Staatliches Museum für Tierkunde Dresden 34(15): 127-135.

Schülke, M. 2003: Eine neue Art und neue Funde von Arten der Ischnosoma spelaeum-Gruppe aus Anatolien (Coleoptera, Staphylinidae, Tachyporinae). - Linzer Biologische Beiträge 35(1): 453-460. "http:/// Www.zobodat.at/pdf/LBB_0035_1_0453-0460.pdf [accessed 2017/11/07].

Schülke, M. 2007: On the Turkish species of the genus Ischnosoma (Insecta: Coleoptera: Staphylinidae: Tachyporinae). - Entomological Problems 37(1-2): 21-30.

Schülke, M. \& Smetana, A. 2015: Staphylinidae, pp. 304-1134. - In:LöвL, I. \& LöвL, D. (eds), Catalogue of Palaearctic Coleoptera. Volume 2. Hydrophiloidea - Staphylinoidea. Revised and updated edition. Brill, Leiden. - ISBN 9789004289925. 


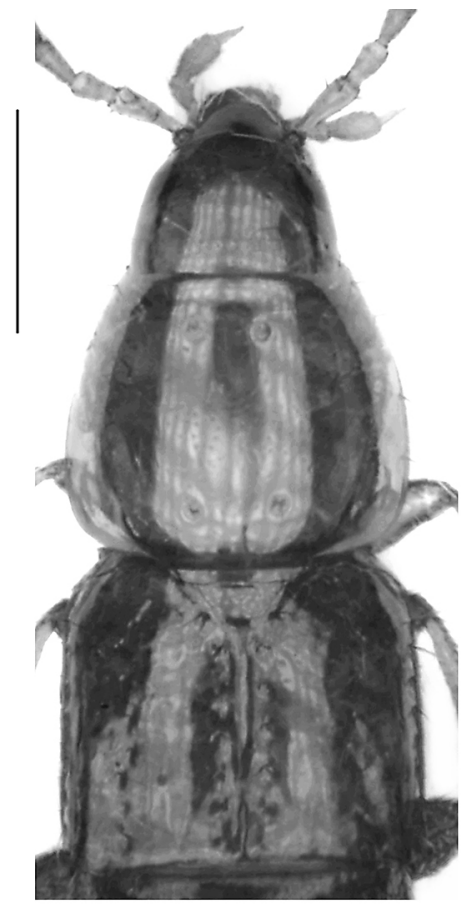

1

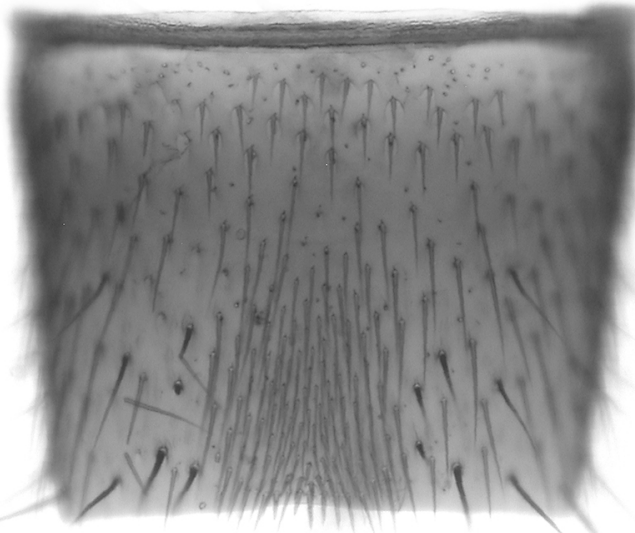

2

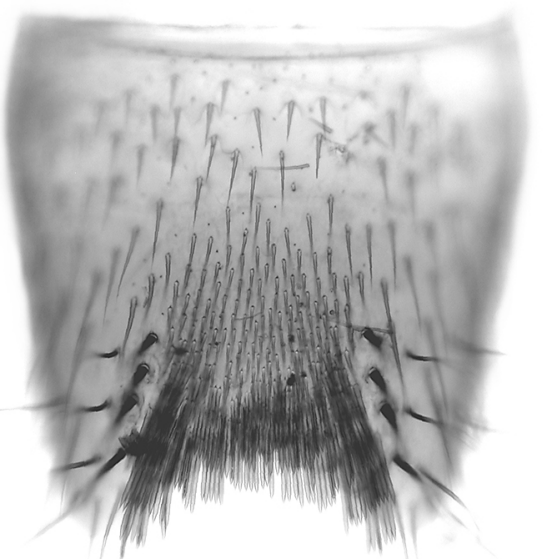

4

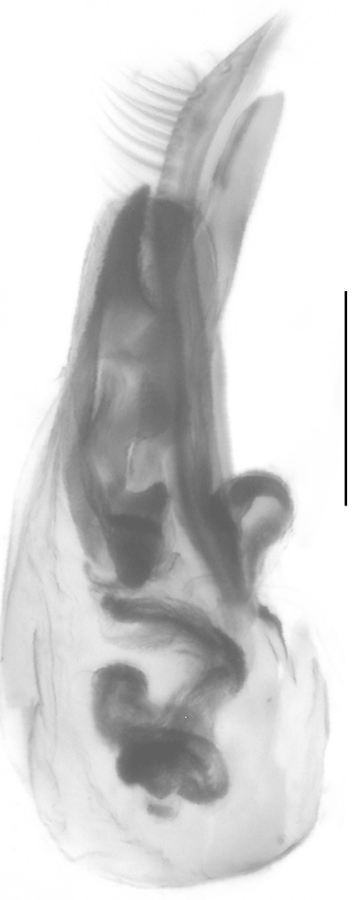

6

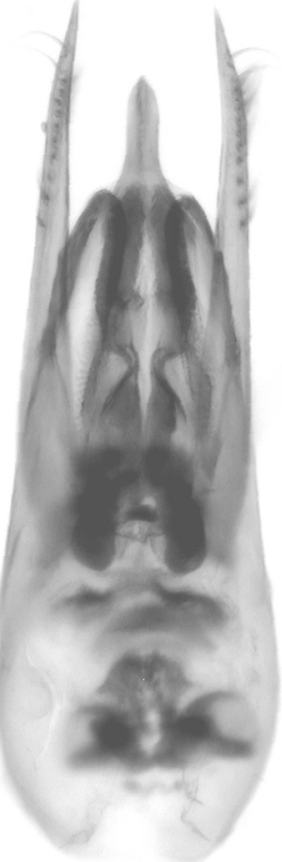

7

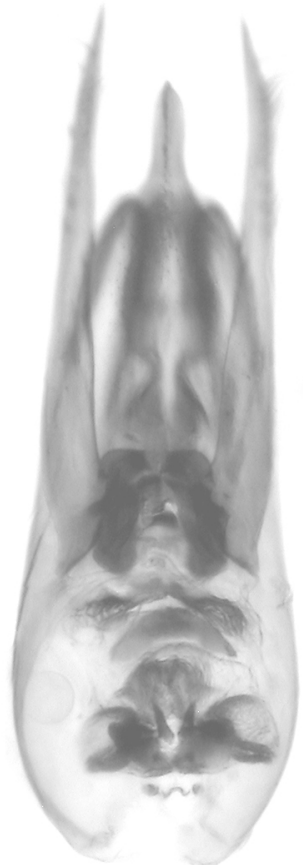

8

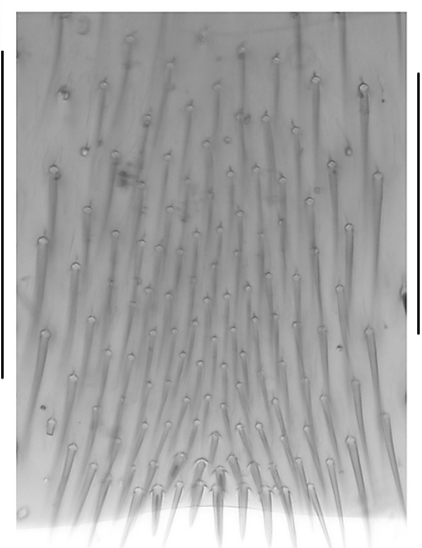

3

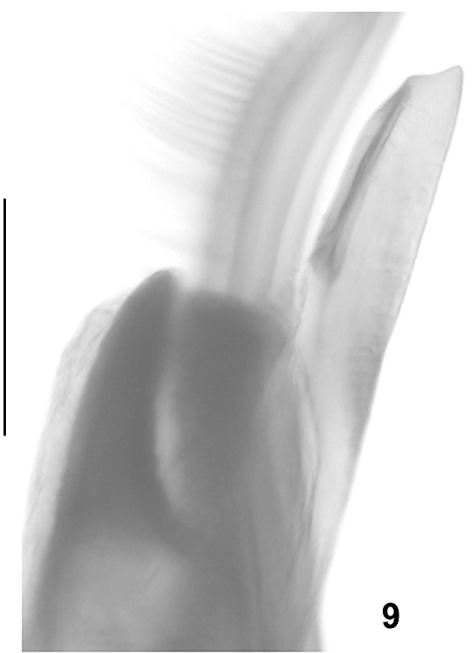

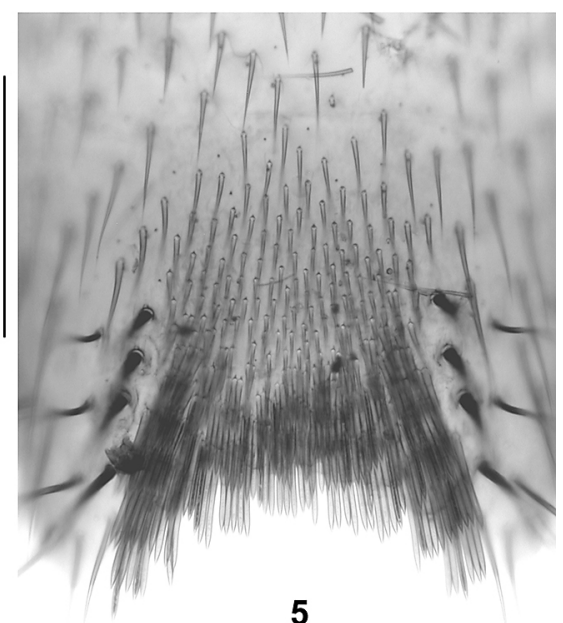

5

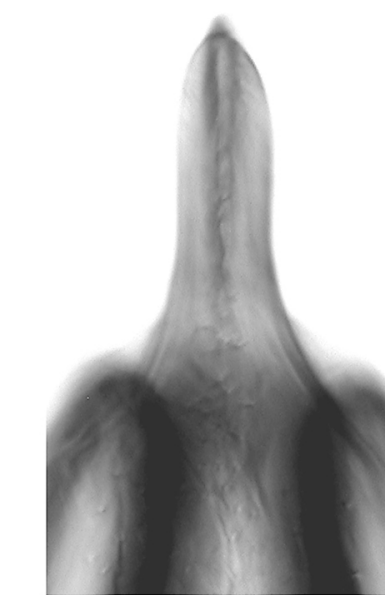

Figs 1-10: Ischnosoma acutum spec. nov.: forebody (1); male sternite VII (2); postero-median portion of male sternite VIII (3); male sternite VIII (4); postero-median portion of male sternite VIII (5); median lobe of aedeagus in lateral and in ventral view (6-8); apex of ventral process of aedeagus in lateral and in ventral view (9-10). Scale bars: 1: 0.5 mm; 2-8: 0.2 mm; 9-10: 0.1 mm. 


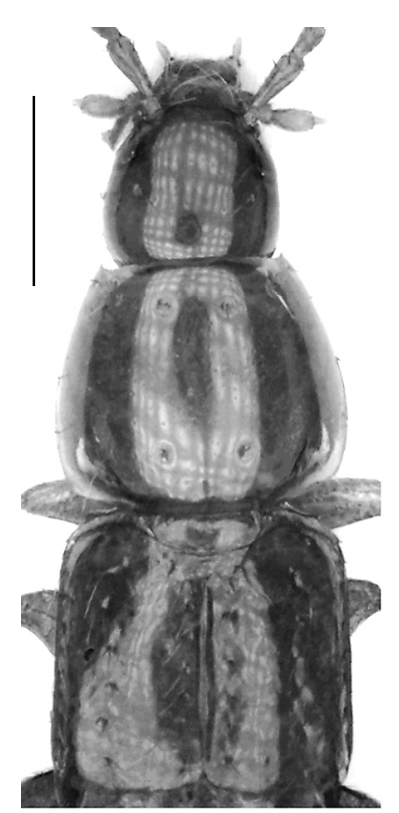

11
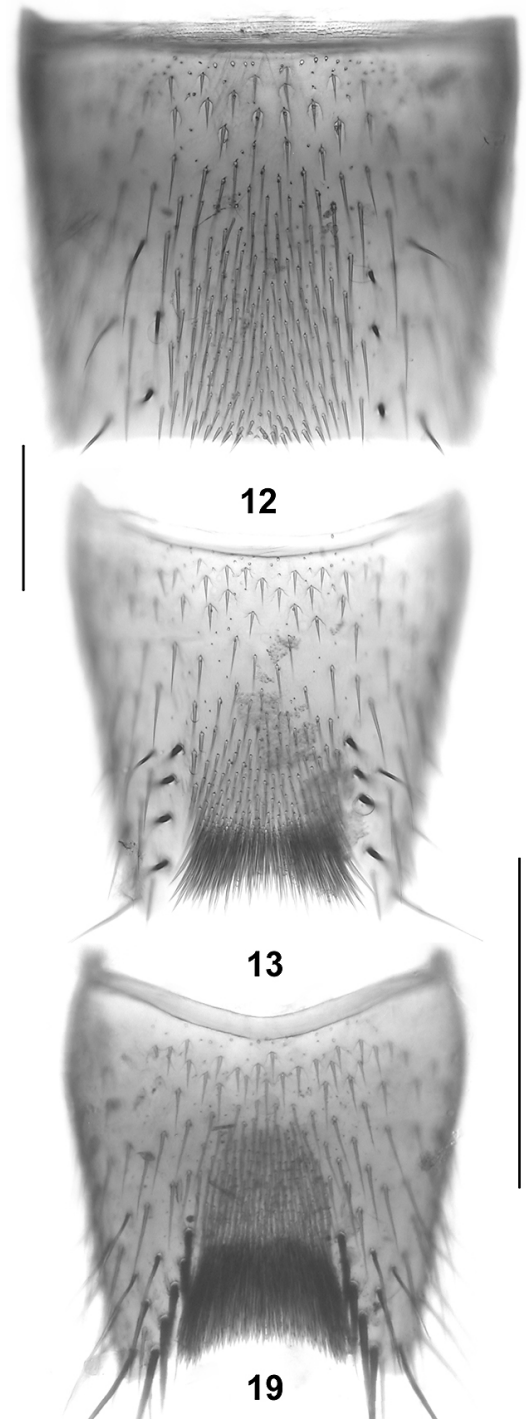

Figs 11-23: Ischnosoma barbigerum spec. nov. (11-18) and I. caucasicum from Krasnaya Polyana (19-23): forebody (11); male sternite VII (12); male sternite VIII $(13,19)$; postero-median portion of male sternite VIII $(14,20)$; $(15-16,21-22)$ median lobe of aedeagus in lateral and in ventral view; apex of ventral process of aedeagus in lateral and in ventral view (17-18, 23). Scale bars: 11: $0.5 \mathrm{~mm} ; 12-16,19-22: 0.2 \mathrm{~mm} ; 17-18,23: 0.1 \mathrm{~mm}$. 


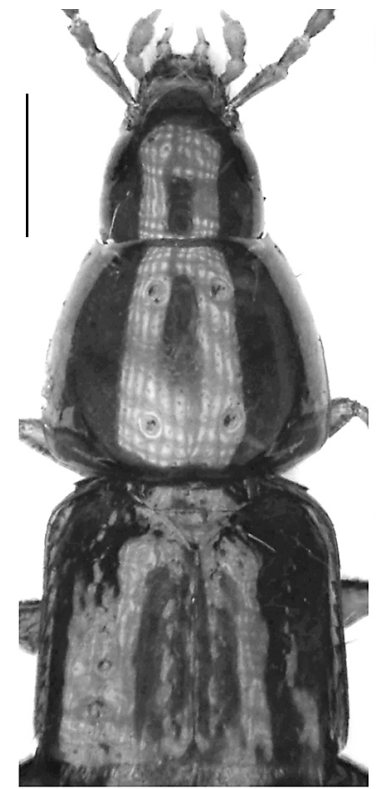

24

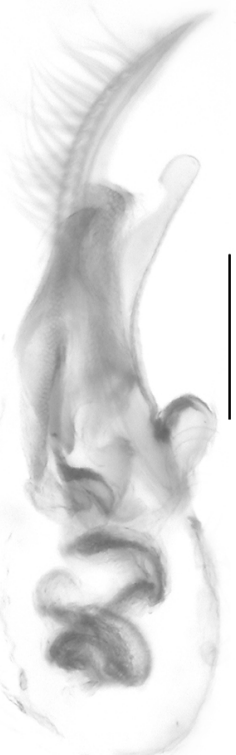

29

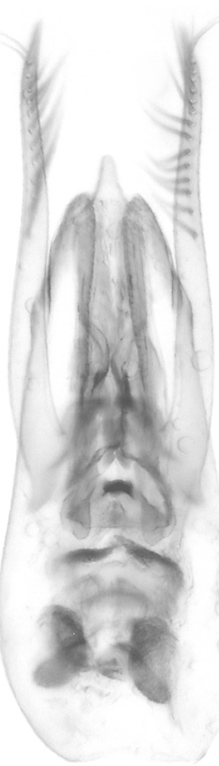

30

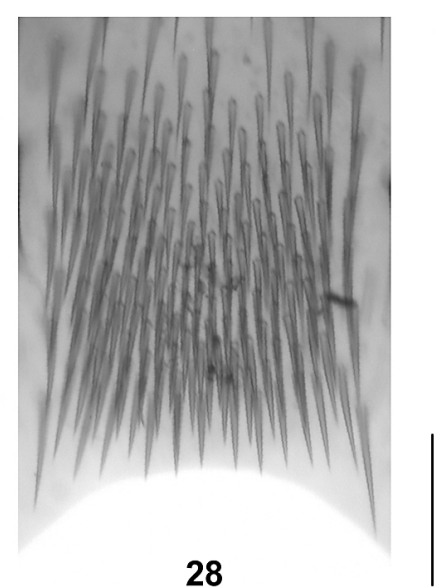

28

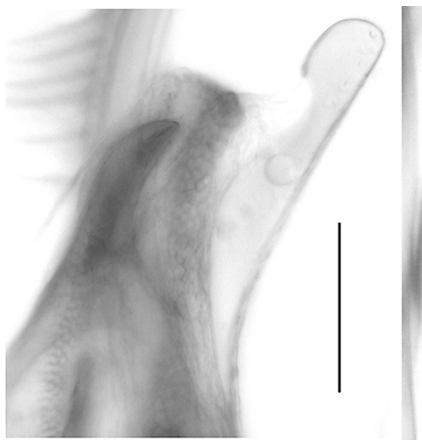

31

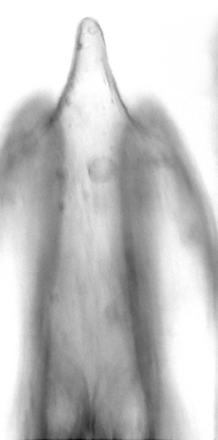

32

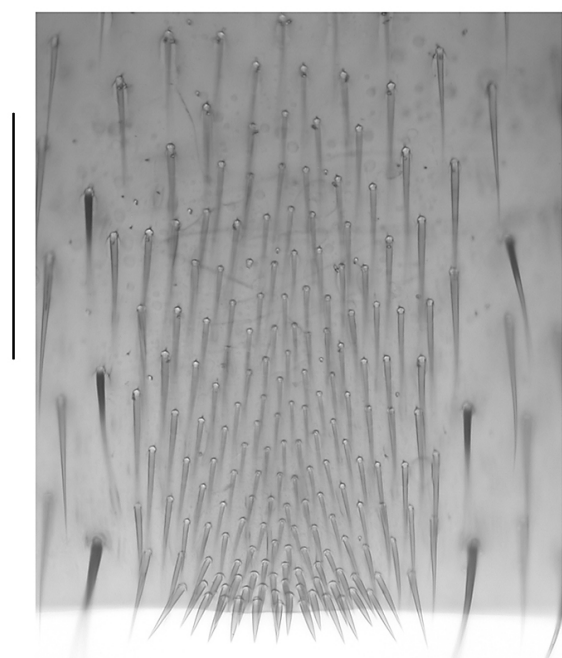

26

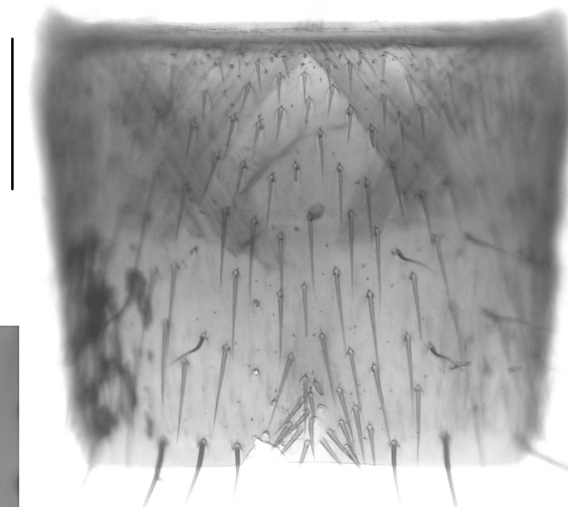

34

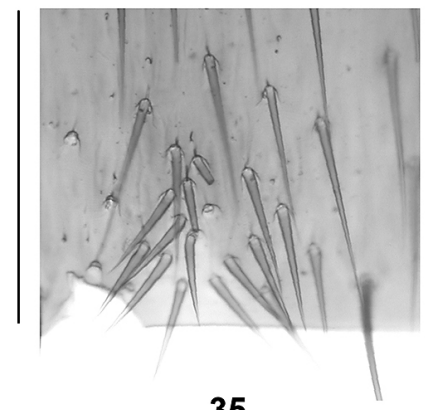

33

Figs 24-35: Ischnosoma molle spec. nov. (24-32), I. barbigerum spec. nov. (33), and I. caucasicum, paratype (34-35): forebody (24); male sternite VII $(25,34)$; postero-median portion of male sternite VIII $(27,33,35)$; male sternite VIII (27); postero-median portion of male sternite VIII (28); median lobe of aedeagus in lateral view (29-30); apex of ventral process of aedeagus in lateral and in ventral view (31-32). Scale bars: 24 : $0.5 \mathrm{~mm}$; 25-30, 33-35: $0.2 \mathrm{~mm}$; 31-32: $0.1 \mathrm{~mm}$. 


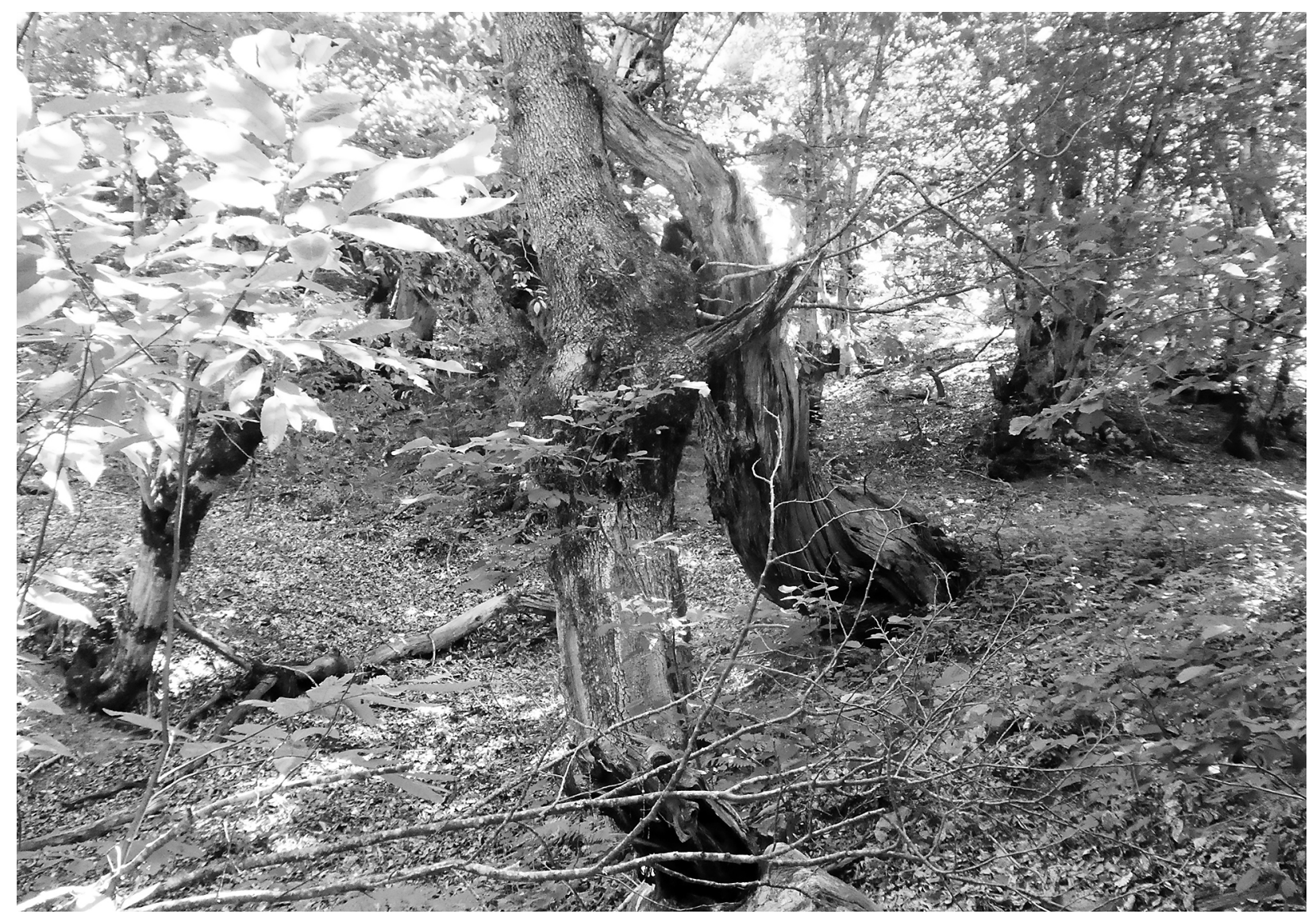

Fig. 36: Type locality of Ischnosoma acutum spec. nov. Photo: Heinrich Meybohm.

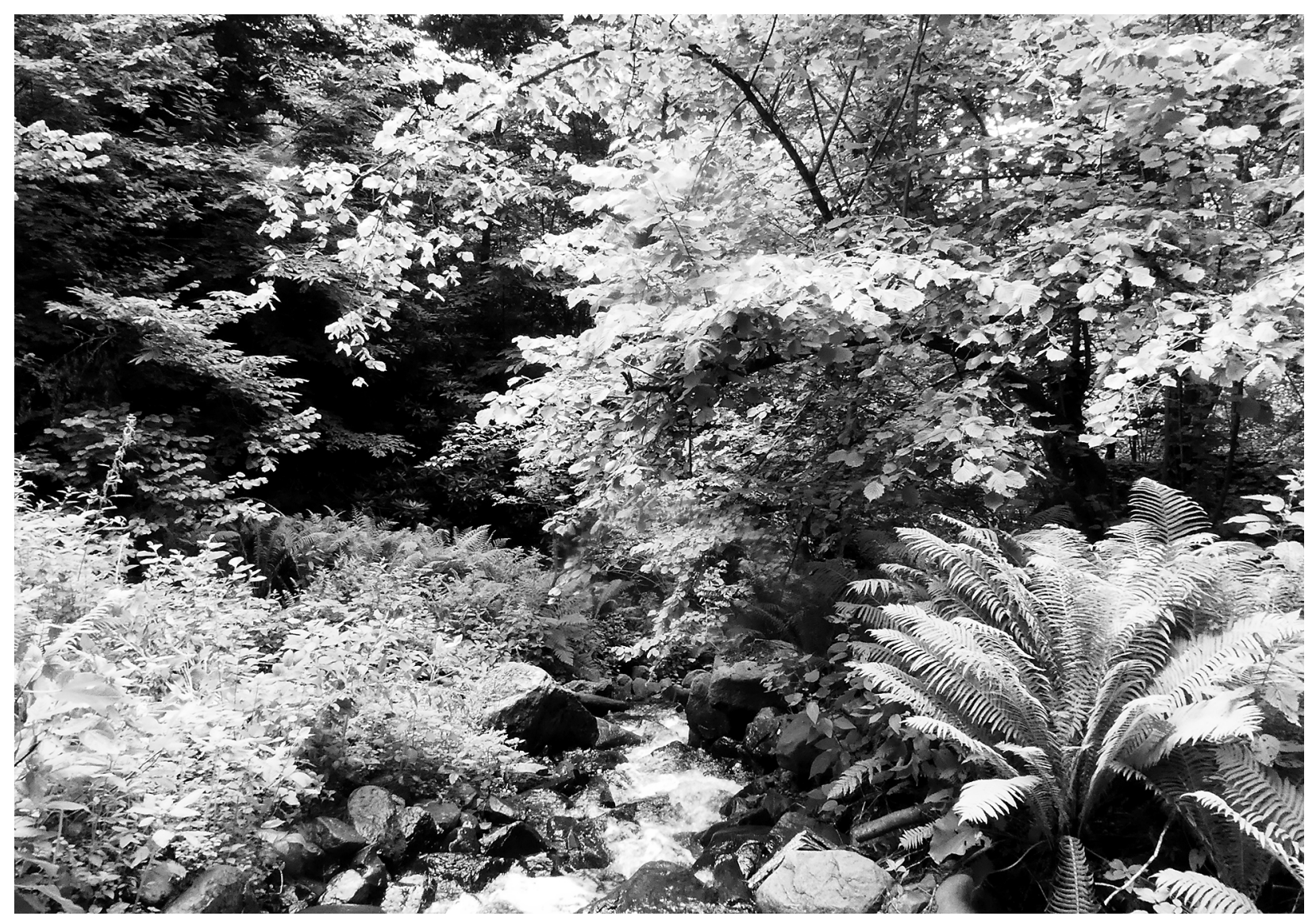

Fig. 37: Type locality of Ischnosoma barbigerum spec. nov. Photo: Heinrich Meybohm. 